\title{
Disaster Risk Analysis (DRA): Case Studies from Pithoragarh district, Uttarakhand, India.
}

\author{
${ }^{1}$ Vedika Pant, ${ }^{2}$ Prof. Ravindra K. Pande \\ ${ }^{1,2}$ Department of Geography, D. S. B. Campus Kumaun University, Nainital. India
}

\begin{abstract}
The word "Disaster Risk Analysis" is combination of three stipulations, having their unique entity impact, where disaster signify natural and manmade disasters, risk indicate the exposure, resistance, resilience, vulnerability, hazard concentration level of the disasters and analysis means used methodologies and techniques. They all are unified in DRA. Pithoragarh is a Himalayan district lies in MCT (Main Central Thrust) zone of Uttarakhand where climate, vegetation and community status greatly vary with elevation. Highly prone to landslides, earthquakes, forest fire, flash flood, drought etc. The main purpose of this paper is to illustrate the vulnerability and risk scenario of Pithoragarh, community participation echelon, administrative set- up and suggest a disaster management action plan.
\end{abstract}

Keywords- Case studies, Disasters, Exposure, GIS, GPS, PRA tools, Resilience, Resistance, Risk analysis. Vulnerability.

\section{INTRODUCTION}

Hazard is an event which has the potential to create losses (such as life, property, environment etc) and when community and community related activities involve with hazard then we call it disaster.

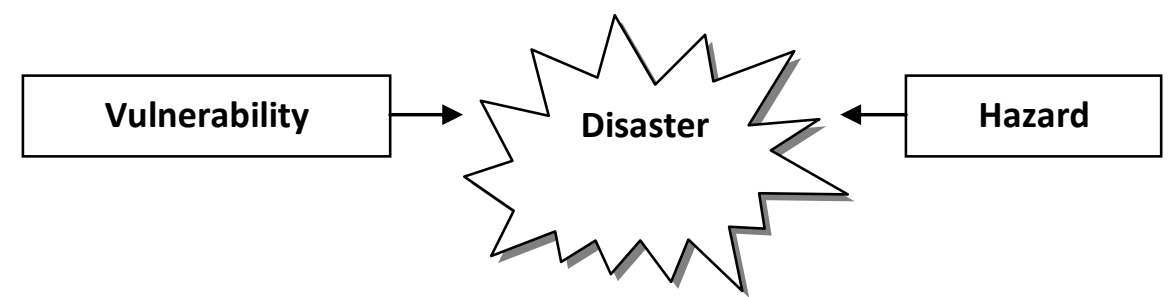

Disaster risk analysis reflects the concept of the disasters as the outcome of continuously present conditions of risk. Disaster risk comprises different type of potential losses which are difficult to quantify, nevertheless [1], the knowledge of the prevailing hazards and the patterns of population and socio economic development. Disaster risk includes the communities' exposure resistance, resilience, vulnerability etc. In simple words "Disaster risk is the probability of a hazard occurring and creating a loss" [2.3]. The objectives of this study are as follows:

1) To study Pithoragarh as a difficult and challenging region.

2) To calculate the exposure, resistance, resilience, vulnerability, risk, management status of the region,

3) To distinguish the role of these components in community participation.

\section{METHODOLOGY}

The methodologies adopted for the presented study are:

1) Primary data collected with the help of PRA (Participatory Rural Appraisal) tools and interviews.

2) Secondary data collected from different books, institutes, organizations, websites, articles etc, for analyzing, explaining, and combining the information from the primary source with auxiliary information.

3) Interpret data analysis and document information.

4) GPS, Ilwis 3.7, and Statistica 8 were also used for geo referencing, mapping and clustering and other purposes.

\section{III.1 About study area}

\section{CASE STUDIES}

Pithoragarh is the easternmost Himalayan district in the state of Uttarakhand, India. It is unsurprisingly landscaped with high Himalayan mountains, snow capped peaks, passes, valleys, alpine meadows, forests, waterfalls, perpetual rivers, glaciers and springs. The flora and fauna of Uttarakhand has rich ecological diversity. The geographical area of the district is $7,100 \mathrm{~km}^{2}$ (2,700 sq mi) [4]. In Pithoragarh, MCT (Main Central Thrust) subsists; MCT is an imaginary line which separates greater and lesser Himalayas, and from 
Disaster Risk Analysis (DRA): Case Studies from Pithoragarh District, Uttarakhand, India.

earthquake/seismic standpoint it lies in zone V. The whole region is highly prone to landslides, earthquakes, forest fire, cloud burst, flash flood, drought etc.

\section{III.2 Selection of villages}

For the present study authors have taken two most inaccessible and difficult blocks from Pithoragarh district (Dharchula and Munsyari) and than three most risk prone villages from each block (from Dharchula"Baram, Lumti, Jarajibli" and from Munsyari "Madkot, Dhapa, Talla dumar"). The selected villages and their locations are given in the Table 1 and Fig 1 and their basic information on Table 2.

Table 1. Selected villages and their geo references

\begin{tabular}{|c|c|c|c|c|}
\hline S.No & Village Name & Block Name & $\begin{array}{c}\text { District } \\
\text { Name }\end{array}$ & Lat/Long of the Village \\
\hline $\mathbf{1}$ & BARAM & Dharchula & Pithoragarh & $80^{\circ} 21^{\prime} 23.725 " \mathrm{E} 29^{\circ} 51^{\prime} 00.079 " \mathrm{~N}$ \\
\hline $\mathbf{2}$ & LUMATI & Dharchula & Pithoragarh & $80^{\circ} 19^{\prime} 27.023^{\prime \prime} \mathrm{E} 29^{\circ} 53^{\prime} 01.792^{\prime \prime} \mathrm{N}$ \\
\hline $\mathbf{3}$ & JARAJIBLI & Dharchula & Pithoragarh & $80^{\circ} 19^{\prime} 33.758^{\prime \prime} \mathrm{E} 29^{\circ} 55^{\prime} 47.911^{\prime \prime} \mathrm{N}$ \\
\hline $\mathbf{4}$ & MADKOT & Munsyari & Pithoragarh & $80^{\circ} 17^{\prime} 43.044^{\prime \prime} \mathrm{E} 30^{\circ} 03^{\prime} 36.051^{\prime \prime} \mathrm{N}$ \\
\hline $\mathbf{5}$ & DHAPA & Munsyari & Pithoragarh & $80^{\circ} 14^{\prime} 19.654^{\prime \prime} \mathrm{E} 30^{\circ} 06^{\prime} 54.693^{\prime \prime} \mathrm{N}$ \\
\hline $\mathbf{6}$ & DUMAR TALLA & Munsyari & Pithoragarh & $80^{\circ} 15^{\prime} 21.094^{\prime \prime} \mathrm{E} 30^{\circ} 06^{\prime} 37.501^{\prime \prime} \mathrm{N}$ \\
\hline
\end{tabular}
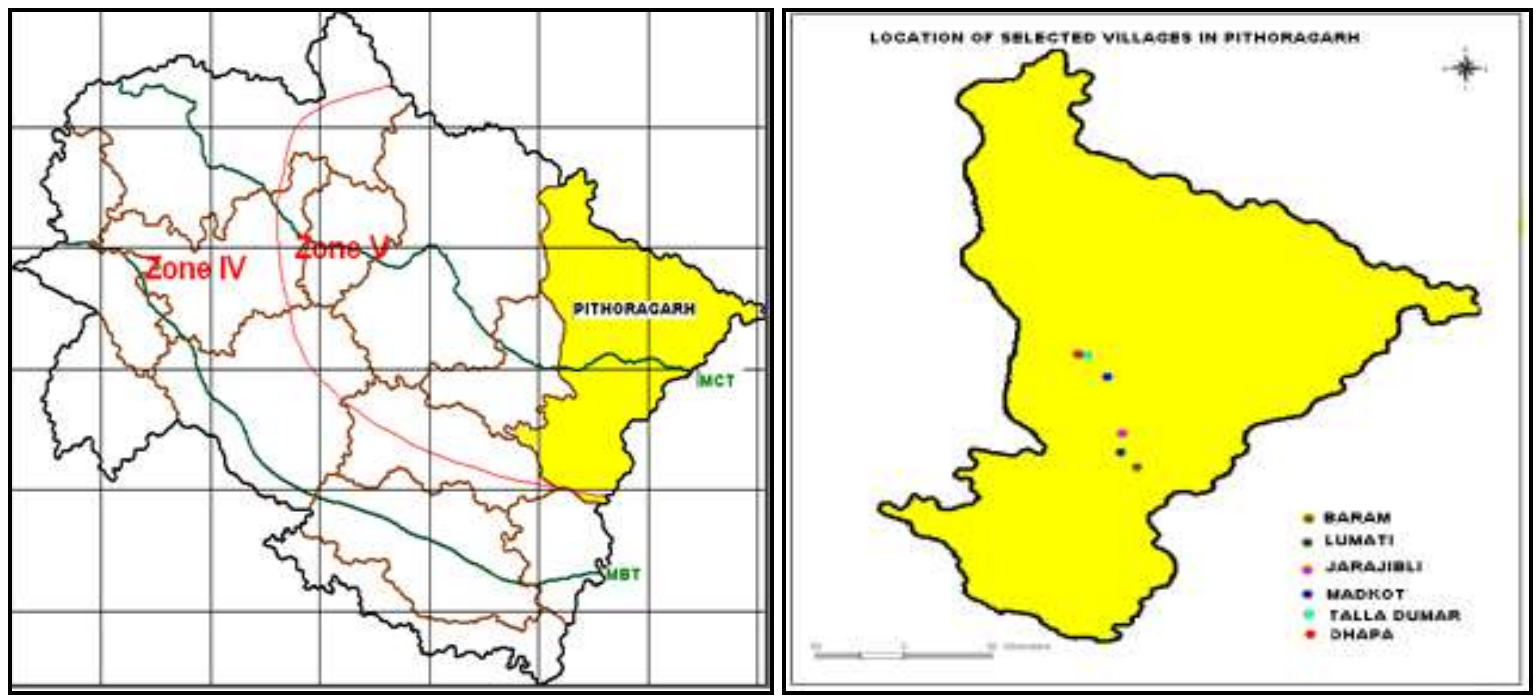

Fig 1: Location of pithoragarh in uttarakhand and Fig 2: Location of selected villages

Table 2: Basic information of the selected villages.

\begin{tabular}{|c|c|c|c|c|}
\hline $\begin{array}{l}\text { Village } \\
\text { Name }\end{array}$ & $\begin{array}{c}\text { Total } \\
\text { Population }\end{array}$ & $\begin{array}{c}\text { Transportation } \\
\text { Medium }\end{array}$ & Main Crops & Hazards \\
\hline BARAM & 1800 & Private Jeeps & $\begin{array}{c}\text { Paddy, Wheat, Maize, } \\
\text { Maduva }\end{array}$ & $\begin{array}{l}\text { Landslide, } \\
\text { Earthquake. }\end{array}$ \\
\hline LUMATI & 355 & Private Jeeps & Wheat, Paddy & $\begin{array}{c}\text { Landslide, } \\
\text { Earthquake, Forest } \\
\text { fire. }\end{array}$ \\
\hline JARAJIBLI & 1500 & $\begin{array}{l}\text { Bridle path to } \\
\text { village only }\end{array}$ & $\begin{array}{c}\text { Paddy, Wheat, Maize, } \\
\text { Maduva }\end{array}$ & $\begin{array}{c}\text { Landslide, } \\
\text { Earthquake, Forest } \\
\text { fire, Flash Flood. }\end{array}$ \\
\hline MADKOT & 1218 & Bus, Jeeps & $\begin{array}{c}\text { Paddy, Wheat, Maize, } \\
\text { Maduva }\end{array}$ & $\begin{array}{l}\text { Landslide, } \\
\text { Earthquake. }\end{array}$ \\
\hline DHAPA & 550 & $\begin{array}{l}\text { Bridle path to } \\
\text { village only }\end{array}$ & Wheat, Maduva & $\begin{array}{c}\text { Landslide, } \\
\text { Earthquake, Forest } \\
\text { Fire, Drought. }\end{array}$ \\
\hline $\begin{array}{l}\text { DUMAR } \\
\text { TALLA }\end{array}$ & 556 & $\begin{array}{l}\text { Bridle path to } \\
\text { village only }\end{array}$ & $\begin{array}{l}\text { Wheat, Paddy, } \\
\text { Maduva }\end{array}$ & $\begin{array}{l}\text { Landslide, } \\
\text { Earthquake }\end{array}$ \\
\hline
\end{tabular}

Source: Based on field survey 2010-2011 
Disaster Risk Analysis (DRA): Case Studies from Pithoragarh District, Uttarakhand, India.

III.3 Vulnerability, Hazard, Management echelon:

Vulnerability, Hazard, Management echelon of the selected villages has been calculated from the data collected through PRA during field visit shown in Table 3.

Table 3: Vulnerability, Hazard and Management scores of the selected villages:

\begin{tabular}{|c|c|c|c|c|c|c|}
\hline $\begin{array}{l}\text { Village } \\
\text { Name }\end{array}$ & $\begin{array}{c}\text { Exposure } \\
(\mathbf{a})\end{array}$ & $\begin{array}{c}\text { Resistance } \\
(\mathbf{b})\end{array}$ & $\begin{array}{c}\text { Resilience } \\
(\mathbf{c})\end{array}$ & $\begin{array}{c}\text { Vulnerability } \\
(\mathbf{a}+\mathbf{b}+\mathbf{c}) \text { /3 }\end{array}$ & Hazard & Management \\
\hline BARAM & 84.61 & 84.21 & 38.63 & 69.15 & 24.16 & 10 \\
\hline LUMATI & 78.92 & 73.68 & 56.81 & 69.13 & 22.16 & 10 \\
\hline JARAJIBLI & 53.84 & 94.73 & 52.27 & 66.94 & 26.00 & 10 \\
\hline MADKOT & 69.23 & 84.21 & 38.63 & 64.02 & 21.83 & 10 \\
\hline DHAPA & 76.92 & 73.68 & 54.54 & 68.38 & 25.50 & 10 \\
\hline $\begin{array}{c}\text { DUMAR } \\
\text { TALLA }\end{array}$ & 69.23 & 78.94 & 52.27 & 66.81 & 21.83 & 10 \\
\hline
\end{tabular}

Source: Based on field survey 2010-2011

\section{III.3 DISASTER RISK ANALYSIS:}

Disaster Risk Analysis of the selected villages is done using the following formula:

$$
\mathbf{R}=(\mathbf{H} * \mathbf{V}) / \mathbf{M}
$$

Here:

$\mathbf{R}=$ Risk,

$\mathbf{H}=$ Hazard,

$\mathbf{V}=$ Vulnerability,

$\mathbf{M}=$ Management [5]

Table 4: Village risk analysis and Fig 3: Risk echelon of the selected villages

\begin{tabular}{|c|c|}
\hline Vilhge Name & $\mathbf{R}=\left(\mathbf{H}^{+} \mathbf{V} \mathbf{M}\right.$ \\
\hline BARAM & 167.06 \\
\hline LUMATI & 153.19 \\
\hline JARAJIBLI & 174.0 \\
\hline MADKOT & 139.75 \\
\hline DHAPA & 174.36 \\
\hline DUMAR TALLA & 145.84 \\
\hline
\end{tabular}

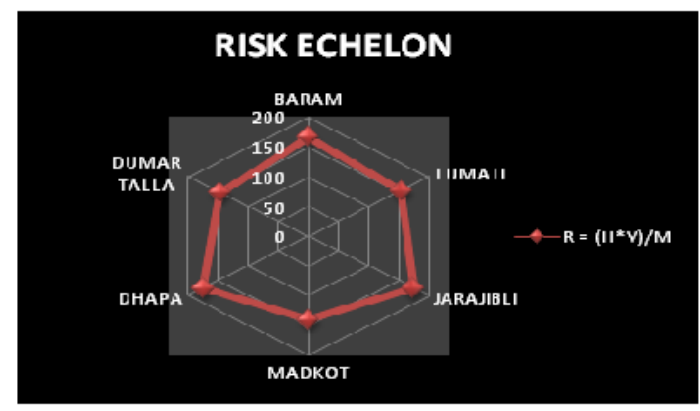

\section{Results}

In village based disaster risk analysis, exposure, resistance and resilience, hazard, management, vulnerability and risk elements have been studied. Exposure level of Jarajibli village (53.84\%) is found very low in comparison to other villages, Resistance level of Lumti village (73.68\%) and Resilience level of Baram village $(38.63 \%)$ is very low. It is a well known fact that exposure is a largely a product of physical location, profession, socio-economic conditions etc and resilience to natural hazard is the ability of an actor to cope with it. The risk of Madkot village is minimum (139.75\%) and Dhapa village is maximum (174.36\%), there are many reasons like social, economic, geographic, political and other factors that affect the overall risk scenario.

\section{Conclusion}

Disasters are either natural or manmade; they simply devastate the region or community and risk is the actual exposure of something of human value to a hazard and is often regarded as the product of probability and loss. For an effective disaster management planning it is important to analyze the disaster risk first [6].

\section{References.}

[1] Glossary - climate-adapt. Available at climate-adapt.eea.europa.eu/glossary[Accessed 06 June 12].

[2] Disaster Risks. Bishnu Pandey and Kenji Okazaki. (2007). unpan1.un.org/intradoc/groups/public/.../un/unpan020698.pdf. Available at http://www.harvardgenerator.com/references/website. [Accessed 06 June 12].

[3] Smith, K., Petley N. D., Environmental Hazards: Assessing Risk and Reducing Disaster, Taylor \& Francis, 13, (2009)

[4] Pithoragarh district from Wikipedia, the free encyclopedia available at en.wikipedia.org/wiki/Pithoragarh_district[Accessed 06 June 12].

[5] Pant V., Pande K. R. Community Based Disaster Risk Analysis (CBDRA): Case Studies from Uttarakhand, India, Global Journal of HUMAN SOCIAL SCIENCE, 12 (4), 44-45, (2012)

[6] Carter, Willam Nick, Disaster management: A disaster Manager's handbook. 1st ed. Manila, Philippines: Asian development bank. (1992). 